vidpovidalnosti [Definition of "misconduct" as a category of public liability]. Forum prava.. № 3. S. 505511. URL : http://www.nbuv.gov.ua/ e-journals/FP/2011-3/11 maappv.pdf. [in Ukr.]

30. Kashkarov, O. O. (2009) Peredumovy reformuvannia Kryminalnoho kodeksu Ukrainy ta stvorennia zakonodavstva pro kryminalni prostupky [Prerequisites for reforming the Criminal Code of Ukraine and creating legislation on criminal offenses]. Forum prava. № 1. S. 236-241. URL : http://nbuv.gov.ua/j-pdf/FP_index.htm_2009_1_36.pdf. [in Ukr.]

31. Pavlyk, L. V. (2012) Perspektyvy vydilennia katehorii kryminalnoho prostupku za zlochynni posiahannia u sferi ekonomiky [Perspectives of selection of the category of criminal misconduct for criminal assault in the economy]. Forum prava. № 2. S. 524-531. URL : http://www.nbuv.gov.ua/ejournals/FP/2012-2/12plvuce.pdf. [in Ukr.]

32. Kos, O. D. (2011) Kryminalnyi prostupok yak strukturnyi element polityky u sferi borotby zi zlochynnistiu [Criminal misconduct as a structural element of anti-crime policy]. Visn. Luhan. derzh. untu vnutr. sprav im. E. O. Didorenka. № 5. S. 130-134. (Spetsvyp.). [in Ukr.]

33. Fris, P. L. (2011) Zlochyn i kryminalna provyna : problemy normatyvnoho zakriplennia [Crime and criminal misconduct: problems of regulatory fixing]. Pravo Ukrainy.. S. 42-49. [in Ukr.]

34. Kryminalnyi prostupok u doktryni i zakonodavstvi [Criminal misconduct in doctrine and legislation]: monohrafiia / avt. kol. : V. O. Tuliakov, H. P. Pimonov, N. I. Mitritsan [ta in.] ; za zah. red. V. O. Tuliakova. Odesa : Yuryd. lit., 2012. 424 s. [in Ukr.]

35. Filosofiya ugolovnogo prava [Philosophy of criminal law] / sost. Yu. V. Golik, A. Yu. Golik ; pod red. Yu. V. Golika. SPb. : Yuryd. tsentr Press, 2004. 348 s. [in Russ.]

36. Makarenko A. S. Shchodo pravovoyi pryrody kryminalnoho prostupku [On the legal nature of criminal misconduct]. URL : http://law-dep.pu.if.ua/conference2014/articles/makarenko.pdf. [in Ukr.]

37. Pro vnesennia zmin do deiakykh zakonodavchykh aktiv Ukrainy shchodo sproshchennia dosudovoho rozsliduvannia okremykh katehorii kryminalnykh pravoporushen [On amendments to some legislative acts of Ukraine regarding simplification of pre-trial investigation of certain categories of criminal offenses]: Zakon Ukrainy vid 22 lystopada 2018 r. № 7279-d. URL : http://w1.c1.rada.gov.ua/pls/zweb2/webproc4_1?pf3511=63928]. [in Ukr.]

\title{
Summary
}

In order to determine the criminal nature of the category of criminal offense, the definition of "criminal offense" as a generic (subsidiary) concept is analyzed and the specific (derivative) concepts of "crime" and "criminal offense" are characterized. Awareness of the essence of the phenomenon of "criminal misconduct" in criminal science has been revealed.

Keywords: criminal offense, crime, criminal offense, criminal procedural law, criminal law.

UDC 347.9

DOI 10.31733/2078-3566-2019-5-189-193

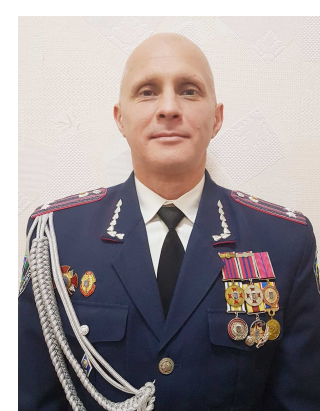

Sergiy BABANIN ${ }^{\circledR}$

Ph.D, Ass. Prof.

(the Dnipropetrovsk State University

of Internal Affairs)

\section{LEGAL PROVISION OF MEDIATION IN UKRAINE}

Сергій Бабанін. ПРАВОВЕ ЗАБЕЗПЕЧЕННЯ МЕДІАЦІї В УКРАЇНІ. Потреба впровадження інституту медіації до правової системи України у цивільний та кримінальний процеси викликана, зокрема, необхідністю розвантаження судової системи України, оскільки завищена кількість справ, які знаходяться в провадженні суддів, не дає можливості здійснювати у повному обсязі належну підготовку та розгляд таких справ. Розглянуті основні положення внесених до Верховної Ради України проектів Закону «Про медіацію» № 2480-1 від 09 квітня 2015 р. та № 3665 від 17 грудня 2015 р. Запропоновані визначення медіації, медіатора, сфери застосування медіації, видів спорів, по яких проведення медіації доцільно встановити обов'язковим, угоди за результатами медіації. Так, під медіацією слід розуміти позасудове врегулювання спору за участю нейтральної сторони - медіатора, який шляхом ведення перемовин зі сторонами спору досягає прийняття цими сторонами взаємовигідного для них рішення.

Медіатором є фізична особа, яка внесена до Сдиного реєстру медіаторів України,

(C) Babanin S., 2019

ORCID iD: https://orcid.org/0000-0002-8424-8825

babanin-s@ukr.net 
держателем якого $\epsilon$ Міністерство юстиції України, або до реєстру медіаторів країни - члена Європейського Союзу. Мінімальний вік медіатора в Україні, який може проводити медіацію по спорах, пов'язаних 3 порушенням тих чи інших нормативно закріплених прав, доцільно встановити у двадцять п'ять років, а також передбачити обов'язковість наявності у нього вищої юридичної освіти та стажу професійної діяльності у сфері права щонайменше три роки. У Законі України «Про медіацію» доцільно передбачити перелік спорів, по яких проведення медіації встановити обов'язковим. Крім того доцільно визнати угоду за результатами медіації обов'язковою для виконання сторонами у визначені ним строки. У разі ж невиконання стороною взятих на себе зобов'язань передбачити їх виконання у порядку, встановленому Законом України «Про виконавче провадження».

Ключові слова: медіація, медіатор, сфери застосування медіації, угода за результатами медіації, позасудове вирімення спорів.

Problem statement. Ukraine has become one of the 46 countries to have signed the UN Convention on International Agreements on Mediation in Singapore on 7 August 2019 [1]. This Convention seeks to facilitate and facilitate the implementation of the decisions reached by the parties in the course of mediation in international commercial disputes. At the same time, it lays the foundation for the introduction of a mediation institute into the legal system of Ukraine. The introduction of this institute connects the modern development of the legal system of Ukraine with the European legal systems, values and priorities of development of the modern civilized world [2, p. 1]. The need to implement this institute in civil and criminal cases is, in particular, a necessity for unloading the judicial system of Ukraine, since the excessive number of cases in the proceedings of judges does not allow proper preparation and consideration of such cases. Thus, the burden on one judge is about 70 cases per year (and, for example, in 2011, this figure was 140 cases). For example, in Germany, the burden on a judge is 55 cases and materials per year, which is considered an overload of the judicial system. The recommendations of the European institutions unanimously urge the member states of the Council of Europe not to increase but to reduce the judicial burden. Such provisions are, in particular, contained in the recommendations of the Committee of Ministers of the Council of Europe: No. R (81) 7 on measures to facilitate access to justice; No. R (99) 19 on mediation in criminal matters; No. Rec (2001) 9 on alternatives to litigation between administrative authorities and private parties; No. Rec (2002) 10 on mediation in civil matters [3].

Analysis of publications that started solving this problem. The question of introduction of the institute of mediation in the legislation of Ukraine is relatively new, but the basics of its research were initiated in the works of R.F. Arakelyan, G.P. Vlasova, I.A. Voytyuk, I.V. Gritsyuk, L.V. Golovko, E.V. Georgievsky, T.A. Denisova, I.I. Yemelyanov, V.V. Zemlyanskaya, O.A. Kalganova, D.V. Kovrizhenko, O.M. Kovalenko, N.A. Mazaraki, V.T. Malyarenko, S.I. Oliynyk, O.V. Taran, V.M. Trubnikov, V.V. Topchiy and other scientists.

The article's objective is to develop proposals for legislative regulation of the mediation process in Ukraine.

Basic content. With a view to unloading the courts of Ukraine from minor civil and criminal cases, it is an urgent need to adopt the Law of Ukraine «On Mediation» and to introduce appropriate amendments and additions to other legal acts.

To date, there is no normative definition of mediation in Ukraine. In our view, mediation should be understood as an out-of-court settlement of a dispute involving a neutral party, a mediator who, by negotiating with the parties to the dispute, achieves a mutually beneficial solution for them. The above definition should be fixed in the Law of Ukraine «On Mediation».

Mediation is an alternative method of dispute resolution that, on the one hand, reflects the high level of development of the legal culture of society, and on the other, allows the parties to choose the most effective and acceptable option for them to resolve the dispute on the basis of fundamental principles of law, which reflect the outstanding values of social development, such as good faith, reasonableness, justice, which is also the basis for the implementation of the rule of law in Ukraine [2, p. 30-31].

One of the key issues of the future Law of Ukraine «On Mediation», in our opinion, is to determine the requirements for obtaining the status of mediator.

The draft Laws on Mediation registered in the Verkhovna Rada of Ukraine contain different approaches to this issue.

Thus, the draft Law «On Mediation» No. 2480-1 of April 9, 2015, defines in Art. 5 «Conditions for acquiring mediator status», which may be a mediator who has reached the age of twenty-one years and has undergone professional training in the field of «mediation» in an 
educational institution or organization in Ukraine or abroad. The mediator may not be a person who is recognized by the court as restricted or incapacitated. Vocational training of mediators must include at least one hundred and twenty academic hours of theoretical and practical training, the last of which must be at least sixty academic hours. The presence of a mediator's professional training shall be certified by a diploma, certificate, certificate or other document issued in the name of the mediator, which shall contain information on the volume (number of hours) of theoretical and practical training, period of study, name of the educational institution or organization that carried out the training [4].

The Draft Law «On Mediation» No. 3665 of 17.12.2015, as of 26.02.2019, defines in Art. 10 «Requirements for a mediator and his special training», which can be a mediator of thirty years of age, has a university degree and has received special training in mediation in Ukraine or abroad. Mediation training must be at least 90 semester hours of primary education, including at least 45 semester hours of practical training. Special training in the field of mediation is provided by legal entities of any form of ownership and organizational and legal form, including educational institutions, one of the activities of which is the activity of professional special training of mediators. The presence of special training of the mediator shall be certified by a diploma, certificate, certificate or other document issued in the name of the mediator, which shall contain information on the amount (number of hours) of training in the field of mediation, the period of study, the name of the legal entity provided for in the second paragraph of this part. A mediator may not be a person: 1) recognized by the court as incapable or limited capacity; 2) having a criminal record not repaid or not withdrawn in the manner prescribed by law; 3 ) dismissed from office as a judge, prosecutor, investigator, from public service or from service in bodies of local self-government for violation of oath, committing a corruption offense; 4) authorized to perform the functions of the state or local self-government; $5)$ which is a public or private contractor [5].

These bills contain significant differences in determining the minimum age of the mediator, as well as the formation of a candidate for mediator.

In our opinion, in determining the minimum age and formation of a mediator, the type of disputes should be taken into account, it can be considered. If these are disputes related to the violation of certain regulatory rights that today only courts have the right to consider, then it is advisable to focus on the requirements for candidates for the position of judge. According to Art. 69 of the Law of Ukraine «On the Judicial System and the Status of Judges», a citizen of Ukraine not younger than thirty and not older than sixty-five years, with a higher legal education and professional experience in the field of law for at least five years, can be appointed competent, virtuous and owning official language [6].

Therefore, the minimum age of a judge is thirty years and the length of service in the field of law is at least five years. However, judges have the right to hear cases of varying complexity. As mediation is intended to deal with minor civil and criminal cases, the requirements for a mediator candidate should, in our view, be somewhat less than for a judge.

We propose to set a minimum age of a mediator in Ukraine, which can mediate disputes related to violation of certain normative rights, in twenty-five years, as well as the obligation to have a higher legal education and professional experience in the field of law for at least three years.

In the Law of Ukraine «On Mediation» we propose to provide the following definition of the term mediator: an individual who is entered in the Unified Register of Mediators of Ukraine, held by the Ministry of Justice of Ukraine, or in the register of mediators of a Member State of the European Union.

Key issues related to the implementation of mediation in Ukraine are determining the scope of its application. As noted by N.A. Mazaraki, a feature of legal regulation of mediation is the combination of state, contractual regulation and self-regulation. The state should establish general principles of the mediation procedure, determine the legal status of the subjects and procedural legal consequences of applying the mediation procedure. In turn, selfregulatory organizations of mediators should set corporate standards of activity, qualification requirements for professional mediators, etc. By concluding mediation agreements, the participants of the mediation determine their rights and obligations in the mediation procedure, the terms and procedure of the mediation itself. Such a dispositive combination will allow to provide versatility and flexibility of regulation of mediation together with ensuring rights of the parties of mediation and third parties by establishing imperative principles [2, p. 31-32].

As mediation can be applied to a wide range of disputes, we agree with the possibility 
and expediency of self-regulation of certain types of mediation. However, we believe that mediation in disputes related to violations of certain statutory rights, which are currently only available to courts, should have a clear regulatory framework.

The Draft Law «On Mediation» No. 2480-1 of 09.04.2015 is defined in Art. 4 «Scope of mediation», which mediation extends to any conflicts provided by this Law, including civil, economic, administrative, labor, family disputes, as well as cases concerning administrative offenses, criminal proceedings in cases provided for in force legislation [4].

The Draft Law «On Mediation» No. 3665 of 17.12.2015, as of 26.02.2019, defines in Art. The «Scope of the Act» specifies that mediation can be applied in any conflict (dispute), including civil, family, labor, economic, administrative, as well as in the proceedings for criminal offenses, crimes of minor or moderate gravity and in criminal proceedings in the form of a private prosecution as provided for in Article 477 of the Criminal Procedure Code of Ukraine, and cases of administrative offenses [5].

The above provisions of the projects do not define a specific list of cases on which the mediation procedure is conducted. We believe that the lack of specifics will not facilitate the effective implementation and implementation of the Mediation Institute in Ukraine.

We propose to provide in the Law of Ukraine «On Mediation» a list of disputes, which make mediation mandatory. In our view, it is advisable to include the following disputes in this list: 1) civil - disputes concerning hereditary rights; 2) family - divorce, separation of property of the spouses, recognition of paternity, disputes over parenting, disputes about participation in the upbringing of the child, determining the place of residence of the child, disputes on ways of fulfilling responsibilities to support the child and determining the amount of alimony, participation in additional expenses for the child , on the duty and amount of alimony for the maintenance of adult children, the maintenance of one spouse; 3 ) labor - all categories of disputes; 4) administrative - unlawful dismissal, renewal at work, recovery of average earnings during forced absenteeism and non-pecuniary damage; 5) criminal - in cases of private prosecution.

Another key issue for the implementation of mediation in Ukraine is the determination of the form and legal force of the document, which is adopted on the basis of mediation.

The Draft Law «On Mediation» No. 2480-1 of 09.04.2015 is defined in Art. 30 «Mediation Agreement» specifies that mediation may result in a mediation agreement. In this case, this agreement is concluded in writing, signed by the parties, the mediator, representatives and / or legal representatives of the parties (if any); includes a joint decision of the parties to settle a conflict between them and / or an obligation to form and procedure for eliminating the damage caused by the conflict; should not contain any provisions that lead to violation of legal or ethical standards; is subject to mandatory execution within the time limit specified by it; in case of non-fulfillment by the party of the obligations assumed by the mediation agreement, the other party has the right to go to court in accordance with the procedure established by law [4].

The Draft Law «On Mediation» No. 3665 of 17.12.2015, as of 26.02.2019, defines in Art. 20 «Mediation Results Agreement», which is a mediation agreement in writing and signed by the parties to the mediation; it must contain a joint decision of the parties to the mediation on the settlement of the conflict (dispute) and be binding on the parties; in case one of the parties to the mediation fails to fulfill its obligations under this agreement, the other party to mediation has the right to go to court in accordance with the procedure established by law [5].

In our view, both bills do not provide the mediation agreement with sufficient legal force, which could significantly impede the implementation of the mediation institute in Ukraine, since the parties will not be interested in resolving the dispute through mediation, but will try to resolve the dispute immediately in court.

We propose to include in the Law of Ukraine «On Mediation» the following provisions: the agreement on the results of mediation is concluded in writing, signed by the parties and the mediator, affixed with the seal of the mediator and entered in the Unified register of agreements on the results of mediation, the holder of which is the Ministry of Justice; each agreement has a separate serial number according to the register; the number under which the transaction is registered is indicated on the form of this agreement issued by the mediator; an agreement on the results of mediation conducted by a mediator of a Member State of the European Union shall be entered in the Unified Register of Agreements on the results of mediation by a mediator of Ukraine on the basis of an agreement; an agreement on the results of mediation is obligatory for the parties to execute it within the deadline set by them; in case of nonfulfillment by the parties of their obligations, their fulfillment shall be conducted in accordance with the procedure established by the Law of Ukraine «On Enforcement Proceedings». 
Conclusions. The proposed provisions for the future Law of Ukraine «On Mediation» will, in our view, facilitate the rapid and effective implementation of this method of out-ofcourt settlement of disputes in the legal practice of Ukraine, and will also serve as a basis for further scientific discussions in this area.

\section{References}

1. United Nations Convention on International Settlement Agreements Resulting from Mediation. URL: http://www.uncitral.org/pdf/english/commissionsessions/ 51st-session/Annex_I.pdf.

2. Мазаракі Н.А. Теоретико-правові засади запровадження медіації в Україні: автореф. дис. ... д-ра юрид. наук : 12.0001 / Ін-т законодавства Верховної Ради України. Київ, 2019. 40 с.

3. Виступ Голови Верховного Суду України Я. Романюка на XII позачерговому з'їзді суддів України 26 вересня 2014 року. URL: https://ics.gov.ua/rsu/129784/.

4. Про медіацію: Проект Закону України від 09.04.2015 p. № 2480-1. URL: http://w1.c1.rada.gov.ua/pls/zweb2/webproc4_1?pf3511=54758.

5. Про медіацію: Проект Закону України від 17.12.2015 p. № 3665 . URL: http://w1.c1.rada.gov.ua/pls/zweb2/webproc4_1?pf3511=57463.

6. Про судоустрій і статус суддів: Закон України від 2 червня 2016 р. № 1402-VIII. URL: https://zakon.rada.gov.ua/laws/show/1402-19?find=1\&text=\%E4\%E2\%E0\%E4\%F6\%FF\%F2\%E8.

Received to editorial office 15.11.2019

1. United Nations Convention on International Settlement Agreements Resulting from Mediation. URL: http://www.uncitral.org/pdf/english/commissionsessions/ 51st-session/Annex_I.pdf. [in Eng.]

2. Mazaraki, N.A. (2019) Teoretyko-pravovi zasady zaprovadzhennya mediatsiyi v Ukrayini [Theoretical and Legal Foundations of Introduction of Mediation in Ukraine]: avtoref. dys. ... d-ra yuryd. nauk : 12.0001 / In-t zakonodavstva Verkhovnoyi Rady Ukrayiny. Kyiv, 40 s. [in Ukr.]

3. Vystup Holovy Verkhovnoho Sudu Ukrayiny YA. Romanyuka na XII pozacherhovomu z"yizdi suddiv Ukrayiny 26 veresnya 2014 roku [Speech by the Chief Justice of the Supreme Court of Ukraine Ya. Romanyuk at the XIIth Extraordinary Congress of Judges of Ukraine on September 26, 2014]. URL: https://ics.gov.ua/rsu/129784/. [in Ukr.]

4. Pro mediatsiyu [On mediation]: Proekt Zakonu Ukrayiny vid 09.04.2015 r. № 2480-1. URL: http://w1.c1.rada.gov.ua/pls/zweb2/webproc4_1?pf3511=54758. [in Ukr.]

5. Pro mediatsiyu [On mediation]: Proekt Zakonu Ukrayiny vid 17.12.2015 r. № 3665. URL: http://w1.c1.rada.gov.ua/pls/zweb2/webproc4_1?pf3511=57463. [in Ukr.]

6. Pro sudoustriy i status suddiv [On Judiciary and Status of Judges]: Zakon Ukrayiny vid 2 chervnya 2016 r. № 1402-VIII. URL: https://zakon.rada.gov.ua/laws/show/140219 ? find $=1 \&$ text $=\% \mathrm{E} 4 \% \mathrm{E} 2 \% \mathrm{E} 0 \% \mathrm{E} 4 \% \mathrm{~F} 6 \% \mathrm{FF} \% \mathrm{~F} 2 \% \mathrm{E} 8$. [in $\mathrm{Ukr}$.]

\section{Summary}

The article deals with research of issues of introduction of the institute of mediation in the legislation of Ukraine. The main provisions of the draft Laws on mediation submitted to the Verkhovna Rada of Ukraine No. 2480-1 of 09.04.2015 and No. 3665 of 17.12.2015 are proposed. The definitions of mediation, mediator, scope of mediation, types of disputes over which mediation is conducted it is advisable to set binding, mediation-based agreements.

Keywords: mediation, mediator, fields of application of mediation, agreement on mediation results, out-of-court settlement of disputes. 